\title{
OPTIMIZATION OF ULTRASOUND ASSISTED EXTRACTION OF POLYPHENOLS IN COCOA BEANS
}

\author{
OPTIMIZACIÓN DEL PROCESO DE EXTRACCIÓN POR ULTRASONIDO DE \\ POLIFENOLES EN GRANOS DE CACAO
}

Jonny Ariel FAJARDO DAZA ${ }^{1 \star} \mathbb{C}^{\circ}$, Carol Andrea IBARRA ${ }^{2}$. David ARTURO PERDOMO ${ }^{1}$ (D) Frank Carlos HERRERA RUALES ${ }^{1,3}$ (D)

Received: 17 sept 2019 Approved: 01 June of 2020

\begin{abstract}
Background: The determination of polyphenols in cocoa beans allows the establishing of antioxidant properties of great benefit to this product. Objectives: Optimization of the ultrasound-assisted extraction method to determine the content of polyphenols in cocoa beans. Methods: Two experiments design stages were carried out to optimize the ultrasound-assisted extraction process of polyphenols from the cocoa bean. In the first experiment design stage, the adequate extraction solvent was determined; for this purpose, five types of solvents were evaluated through a completely random design unrestricted (CRD). In the second experiment stage, a central composite design $2^{2}+$ star point (with two central points) was used, which was evaluated using the response surface methodology to determine the influence of the temperature, time, and solute / solvent ratio. Results: The experiment found that acetone: water: acetic acid (70: 29.5: 0.5) mixturee, leads to a greater amount of total extracted phenols measured for the FolinCiocalteu method. Analysis of variance (ANOVA) found that six significant effects that influence the response variable (total phenols extracted). The main effects were of the three factors and three of their interactions. Conclusions: After the optimizing said factors, an optimal point was found: $39.3^{\circ} \mathrm{C}$ of temperature, 74.5 minutes, and $22.8 \mathrm{~mL}$ of solvent per gram of cocoa sample.
\end{abstract}

Keywords: Cocoa beans, polyphenols, ultrasound-assisted extraction, Optimization, Experimental design.

\section{RESUMEN}

Antecedentes: La determinación de polifenoles en granos de Cacao permite establecer propiedades antioxidantes de gran valor agregado a este producto. Objetivo: Optimización del método de extracción asistida con ultrasonido para determinar el contenido de polifenoles en granos de Cacao. Métodos: Se realizaron dos etapas del diseño experimental para la optimización del proceso de extracción de polifenoles del grano de cacao por ultrasonido. En la primera etapa se determinó el solvente de extracción más adecuado evaluando cinco tipos de solventes, mediante un diseño completamente al azar sin restricciones (DCA). En la segunda etapa experimental, se usó un diseño central compuesto $2^{2}+$ estrella (con dos

Corporación para Investigación Aplicada al Desarrollo (CIAD). Pasto, Colombia.

Departamento de Química-Universidad de Nariño. Pasto, Colombia.

Ciencias Farmacéuticas y Alimentarias-Universidad de Antioquia. Medellín, Colombia.

Corresponding Author: jonnyariel@yahoo.com 
puntos centrales), que se evaluó mediante la metodología de superficie de respuesta para determinar la influencia de los factores Temperatura, tiempo y relación soluto/solvente. Resultados: Se determinó que la mezcla acetona: agua: ácido acético (70:29.5:0.5) extrae la mayor cantidad de fenoles totales cuantificados por el método de Folin-Ciocalteu. Mediante la aplicación de un análisis ANOVA, se encontró que seis efectos significativos influyen sobre la variable de respuesta (fenoles totales), estos incluyen los efectos principales de los tres factores y tres de sus interacciones. Conclusiones: Después de la optimización de dichos factores se encontró un punto óptimo que corresponde a $39.3{ }^{\circ} \mathrm{C}$ de temperatura, 74.5 minutos y $22.8 \mathrm{~mL}$ de solvente por gramo de muestra de cacao.

Palabras clave: granos de cacao, polifenoles, extracción asistida por ultrasonido, optimización, diseño experimental.

\section{INTRODUCTION}

Many research studies about the properties of polyphenols, mainly their antioxidant capacity, have been significantly addressed in recent decades. The positive health effects of these compounds is of great interest in the science and technology food, mainly in the finding and using natural sources of antioxidant compounds, especially natural products and foods. $(1,2)$.

Among the foods in which a significant percentage of polyphenols have been reported is the Cocoa (Theobroma cacao L.). This food is particularly rich in polyphenols, representing between 12 and $18 \%$ of the beans' dry weight. These compounds are strongly associated with antioxidant activity and with the organoleptic characteristics of the products made from cocoa. (3). The EFSA (European Food Safety Authority) recognized to chocolate and cocoa powder as an important source of polyphenols with outstanding properties for health $(4,5)$.

Proanthocyanins, catechins, or flavan-3-ols and anthocyanins are the major flavonoids in cocoa beans, with 58, 37, and 4 percent (\%) in content, respectively. $(3,4)$. The content and composition of polyphenols in cocoa beans dependent on many factors such as genotype, origin, type of clone, growth conditions, fermentation, drying, and roasting process. $(4,6-7)$.

Various extraction methods have been reported for polyphenol extraction compounds, including heat reflux extraction, Soxhlet extraction, traditional maceration, microwave-assisted extraction, ultrasound-assisted extraction, and supercritical fluids extraction (8-9). In addition to the extraction methods, many factors in the extraction process involve time and temperature of extraction, solvents type, mixture solvents, $\mathrm{pH}$, solute-solvent ratio, and particle size (9-11). The extraction of polyphenols from cocoa beans cover a wide range of variation for each of these factors. For example, various extraction methods like the maceration with solvents to ultrasound-assisted extraction $(3,12)$, extraction times $(13,14)$, diverse solutesolvent ratios $(1: 10-1: 30(\mathrm{w} / \mathrm{v}))(15,16)$. As well as different extraction temperatures: $20-37^{\circ} \mathrm{C}(13$, 17) and various extraction solvents and mixtures solvents such as ethanol-water (80:20), methanolwater (70:30), methanol (100\%) isopropanol-water (60:40) and acetone: water: acetic acid 70:29.5:0.5 $(3,14,17-19) \mathrm{v} / \mathrm{v}$.

The use of ultrasonic radiation $(20-100 \mathrm{kHz})$ to extract natural compounds provides high reproducibility, easy handling, low use of solvents, energy consumption and, temperature, as well as minimizes the losses of bioactive compounds (20). Gil (2012) found that with polyphenols from cocoa, in general, the Ultrasound-Assisted Extraction is more efficient than the conventional extraction by agitation. Quiroz-Reyes et al. (2012), determined that the total polyphenol content of cocoa cotyledon is statistically higher when using the ultrasound method than the maceration with solvents. The extraction time is a fundamental factor because studies have generally found that, as the extraction time increases, the quantity of polyphenols extracted increases as well $(14,21)$. Temperature is an important factor to be taken into account due to its impact on the solubility of the solutes in the solvent and the degradation of thermolabile compounds. Likewise, the solute-solvent ratio is important because it modifies the solubility and the 
maximum amount of total extractable polyphenols (22). Since there is no universal method for the extraction of polyphenols in cocoa beans, it is important to study the influence of these factors on the degree of extraction of said compounds. The main objective of this study was to obtain the highest contents of polyphenols, optimizing the ultrasound-assisted extraction conditions for Colombian cocoa beans from the Pacific Coast in the Nariño region.

\section{MATERIALS AND METHODS}

\section{Materials}

Methanol, acetone, isopropanol, ethanol, acetic acid, and the Folin-Ciocalteu reagent were purchased from Merck (Germany); Gallic acid was obtained from Sigma-Aldrich (USA).

For all experiments, the cocoa samples were collected from regional materials of Consejo Comunitario El Rescate- las Varas from Tumaco, Nariño-Colombia.

\section{EXPERIMENTS}

\section{Extraction solvent selection}

Experiments were carried out using an unrestricted completely random design (CRD) with two replicates, for a total of 15 tests. Factors such as temperature, time extraction, and solutesolvent ratio were kept constant (room temperature at $20^{\circ} \mathrm{C}, 90$ minutes, and $20 \mathrm{~mL}$ of solvent/gram of sample). The five solvents used were: methanol, methanol:water $(70: 30 \mathrm{v} / \mathrm{v})$, isopropanol-water $(60: 40 \mathrm{v} / \mathrm{v})$, ethanol:water $(80: 20 \mathrm{v} / \mathrm{v})$ and acetone: water: acetic acid (70:29.5:0.5 v/v). Statistical significance was examined with analysis of variance (ANOVA) and Tukey test at 95\% confidence.

\section{Optimization Ultrasound-assisted extraction}

After determining the solvent that extracts the highest amount of polyphenols, we proceeded to optimize the extraction factors: temperature, time, and solute/solvent ratio, through the central composite design (CCD) 22 plus stars point and two central points. The number of experiments was 16 plus one replica for a total of 32 experiments. The total polyphenols content was considered the response variable. The interaction variables and experimental data were analyzed using an analysis of variance (ANOVA) and response surface methodology. The data analysis was performed with the Statgraphics Centurion XVI software. Table No. 1 shows a description of the levels of each of these factors.

Table 1. Factors and their levels for central composite design.

\begin{tabular}{|l|c|}
\hline \multicolumn{1}{|c|}{ Factors } & Levels \\
\hline & 20 \\
A) Temperature $\left({ }^{\circ} \mathrm{C}\right)$ & 30 \\
& 40 \\
\hline \multirow{3}{*}{ B) Time (minutes) } & 30 \\
& 60 \\
C) Solute-solvent ratio (w/v) & 90 \\
\hline
\end{tabular}

Cocoa bean extracts were prepared with Brandson ultrasound equipment (USA) with a control temperature selector and operated at a standard frequency. The extract was stored at $-20{ }^{\circ} \mathrm{C}$ in amber vials until further analysis.

\section{Folin-Ciocalteu Method for Total Polyphenols}

The total polyphenol content of the extracts was determined using the Folin-Ciocalteu method, described by Singleton (1965), with some modifications proposed by Wollgast (2004). Briefly, $80 \mu \mathrm{L}$ of extract and $1,250 \mu \mathrm{L}$ of Folin reagent diluted ten times were mixed in a shaker and then $2,000 \mu \mathrm{L}$ of sodium carbonate $(7.5 \%)$ was added. The vials were left for 60 minutes at room temperature in the dark. The absorbance was determined at $765 \mathrm{~nm}$ in a UV-Visible spectrophotometer Genesys $10 \mathrm{~S}$ Thermo Scientific (USA). All of the samples were analyzed in duplicate. The quantitative analysis was performed with a standard external method using calibration curves with gallic acid. (50 -300 $\mu \mathrm{g} / \mathrm{mL})$ and were expressed as $\mathrm{mg}$ of gallic acid equivalent/g per sample.

\section{RESULTS}

\section{Extraction solvent selection}

The ANOVA results of the first stage experiment showed significant differences between conditions of experimentation (the type of solvent) at a level of significance of $95 \%$, as shown in Table 2. The averages of the Tukey's 
significance test showed four differentiated groups. The experiments that employed a solvent mixture of acetone: water: acetic acid (70: 29.5: $0.5)$ was statistically superior compared to the other types of solvents (Table No. 3). This solvent mixture was chosen to carry out the extraction of the polyphenols in the samples.

Table 2. Analysis of variance for solvent types of polyphenols extraction.

\begin{tabular}{|l|c|c|c|c|c|}
\hline \multicolumn{1}{|c|}{ Variance } & Sum of Square & Degree of Freedom & Mean Square & F-calc & F-tab \\
\hline Between Groups & $1,503.3$ & 4.0 & 375.8 & 981.5 & 3.5 \\
\hline Within Groups & 3.8 & 10 & 0.4 & & \\
\hline Total & 1,507 & 14.0 & & & \\
\hline
\end{tabular}

Table 3. Tukey test for solvent types

\begin{tabular}{|l|c|c|}
\hline \multicolumn{1}{|c|}{ Solvent Type (v/v) } & mg GAE / Cocoa $^{(\mathbf{1})}$ & Group \\
\hline Acetone:water: acetic acid (70: 29.5: 0.5) & 33.77 & $\mathrm{~A}$ \\
\hline Methanol: Water (70:30) & 25.23 & $\mathrm{~B}$ \\
\hline Isopropyl alcohol:Water (60:40) & 24.85 & $\mathrm{~B}$ \\
\hline Ethanol:Water (80:20) & 15.81 & $\mathrm{C}$ \\
\hline Methanol & 4.31 & $\mathrm{C}$ \\
\hline
\end{tabular}

${ }^{\star}$ mg of gallic acid equivalent/ g cocoa

\section{Optimization Ultrasound-assisted extraction}

The ANOVA of the CCD indicates six effects that influenced the response variable, which refers to the main effects of the three factors studied and three interactions. The solute-solvent ratio (C) was the most important parameter affecting the total polyphenols content. Likewise, time (B) and temperature $(A)$ of extraction and the interaction temperature: time $(\mathrm{AB})$, temperature: solute- solvent ratio (AC), and quadratic effect of time (BB) showed a significant influence (Figure 1. Pareto chart). Table 4 shows the results of statistical analysis. The main effects plot (Figure 2) illustrates the behavior of the response variable (polyphenols totals) related to the levels of the factors analyzed. The interaction plot shows the relationship among factors analyzed in this work: temperature: time $(\mathrm{AB})$, temperature: $\mathrm{S}-\mathrm{S}$ ratio $(\mathrm{AC})$, and time: $\mathrm{S}-\mathrm{S}$ ratio $(\mathrm{BC})$. (Figure 3).

Table 4. Analysis of variance for Central Composite Design of extraction of the Polyphenols compound.

\begin{tabular}{|l|c|c|c|c|c|}
\hline \multicolumn{1}{|c|}{ Source } & Sum of Square & DF & Mean Square & F -Ratio & P-Value \\
\hline A: Temperature & 25.43 & 1 & 25.44 & 15.25 & $\mathbf{0 . 0 0 0 8}$ \\
\hline B: Time & 39.98 & 1 & 39.98 & 23.98 & $\mathbf{0 . 0 0 0 1}$ \\
\hline C: S / S ratio & 54.89 & 1 & 54.89 & 32.92 & $\mathbf{0 . 0 0 0 0}$ \\
\hline AA & 0.00383 & 1 & 0.00383 & 0.00 & 0.9622 \\
\hline AB & 12.13 & 1 & 12.13 & 7.27 & $\mathbf{0 . 0 1 3 2}$ \\
\hline AC & 8.87 & 1 & 8.87 & 5.32 & $\mathbf{0 . 0 3 0 9}$ \\
\hline BB & 20.062 & 1 & 20.062 & 12.03 & $\mathbf{0 . 0 0 2 2}$ \\
\hline BC & 0.605 & 1 & 0.605 & 0.36 & 0.5533 \\
\hline CC & 1.68 & 1 & 1.68 & 1.01 & 0.3263 \\
\hline Total Error & 36.69 & 22 & 1.67 & & \\
\hline Total (corr.) & 211.99 & 31 & & & \\
\hline
\end{tabular}


Diagram of Pareto Standardization for total Phenols

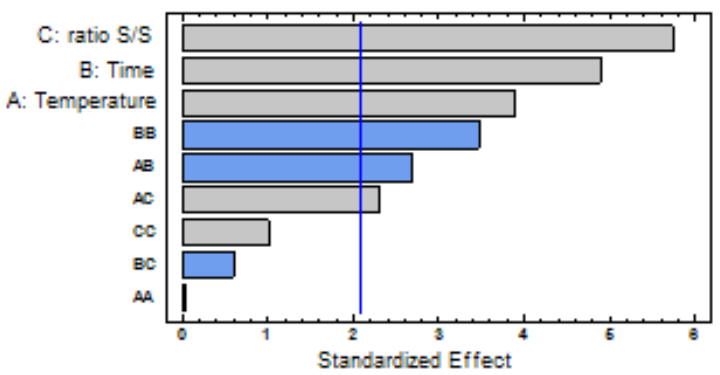

Figure 1. Pareto chart for ultrasound-assisted extraction of polyphenols in cocoa beans. A: Temperature, B: Time, C: $\mathrm{S}-\mathrm{S}$ ratio.

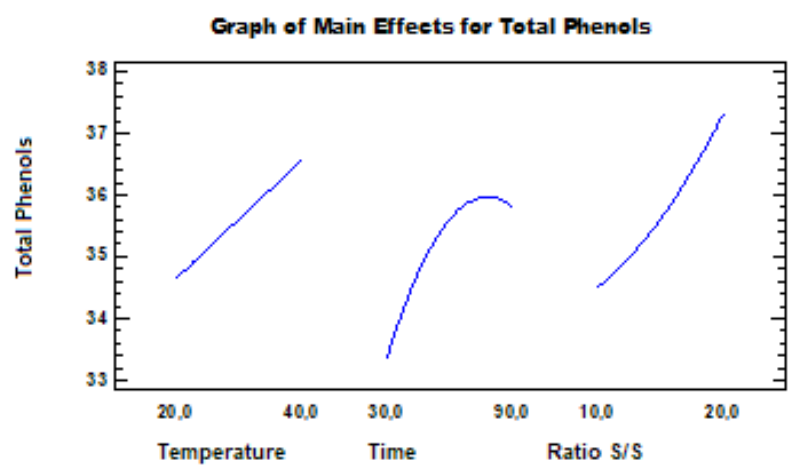

Figure 2. Main effects plot for polyphenols total.

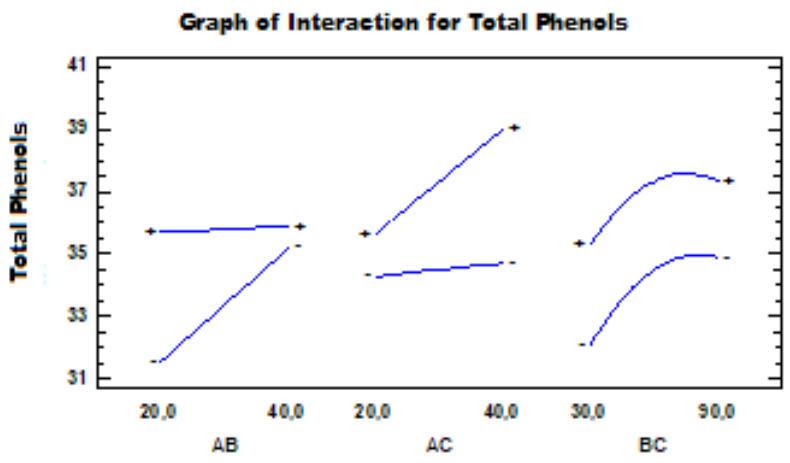

Figure 3. Interaction plot for polyphenols total.

Figures $4-6$ show the response surface plots of temperature vs. time (Figure 4), temperature vs. solute-solvent (Figure 5), and time vs. solutesolvent ratio (Figure 6). The solute-solvent ratio was the factor of greatest influence in the polyphenol's extraction. Polyphenols' value increased along with the S-S ratio. Also, the optimum times and temperatures to extract polyphenols from cocoa beans were above 45 minutes and $30^{\circ} \mathrm{C}$.

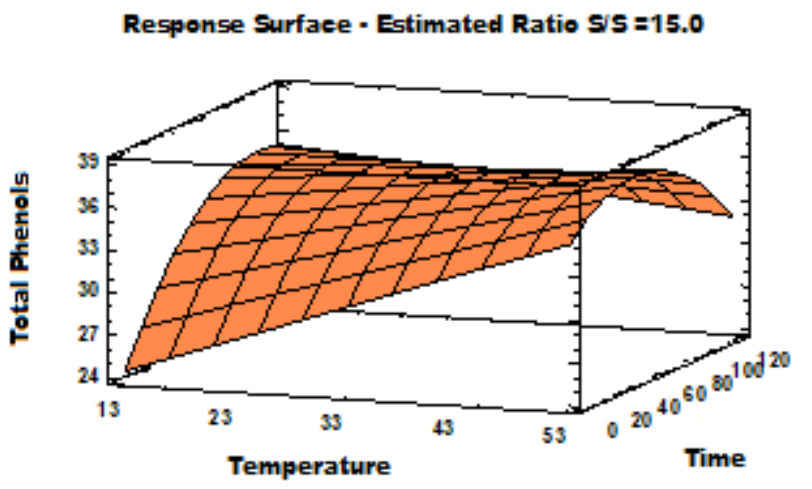

Figure 4. Response surface plot for the effects of temperature and time

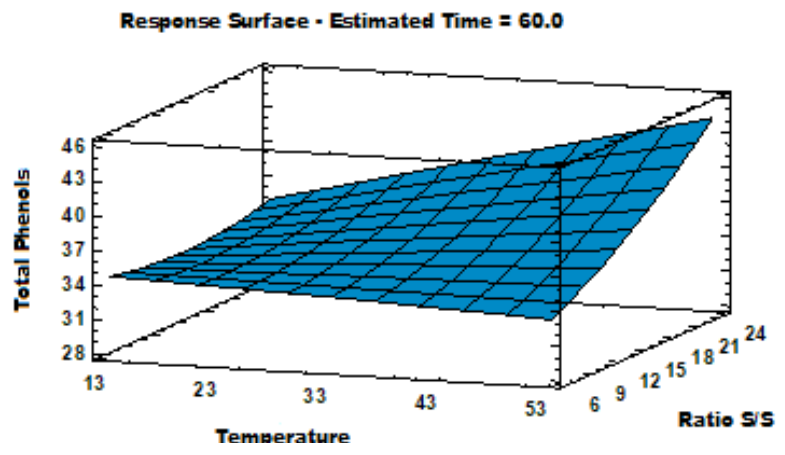

Figure 5. Response surface plot for the effects of temperature and solute-solvent ratio

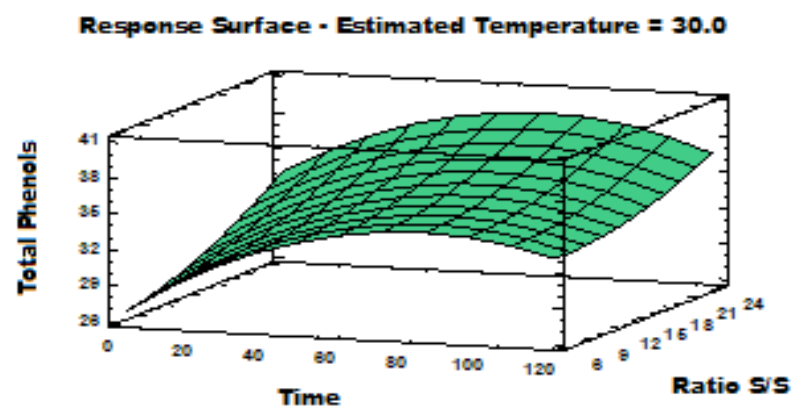

Figure 6. Response surface plot for the effects of time and solute-solvent ratio

The optimal values that maximized the response variable were determined through the optimization of central composite design. The results are shown in table 5. The optimal response (maximum predicted response) predicted with the optimal factors extracts was $40.3 \mathrm{mg}$ gallic acid equivalent/g cocoa. 
Table 5. Optimal Values CCD

\begin{tabular}{|l|c|c|c|}
\hline \multicolumn{1}{|c|}{ Factor } & Low & High & Optimal \\
\hline Temperature & 13.18 & 46.82 & 39.31 \\
\hline Time & 9.55 & 110.45 & 74.46 \\
\hline S -S ratio & 6.59 & 23.41 & 22.79 \\
\hline
\end{tabular}

\section{Total Polyphenols Quantification in Cocoa samples by Folin-Ciocalteu Method}

The analysis of total Polyphenols in cocoa beans samples of regionals materials from TumacoColombia was performed with the optimization conditions described above. Table 6 shows the results of these samples.

Table 6. Contents of total polyphenols in samples of cocoa beans.

\begin{tabular}{|c|c|}
\hline Regional Material & $\mathbf{m g ~ G A E} / \mathbf{g}^{(\mathbf{1})}$ \\
\hline CCL 02 & $59.27 \pm 0.88$ \\
\hline CCL 07 & $50.28 \pm 2.28$ \\
\hline CCL 10 & $43.75 \pm 0.87$ \\
\hline CCL 17 & $56.33 \pm 1.19$ \\
\hline CCL 24 & $5.17 \pm 0.49$ \\
\hline CCL 26 & $56.12 \pm 1.20$ \\
\hline CCL 27 & $41.17 \pm 0.94$ \\
\hline CCL 35 & $50.06 \pm 1.45$ \\
\hline CCL 93 & $35.34 \pm 0.70$ \\
\hline
\end{tabular}

${ }^{\star}$ mg of gallic acid equivalent/ g cocoa $n=3$

\section{DISCUSSION}

The results of the extraction solvent selection are congruent with the reported by Wollgast et al. (2004), in his study regarding the determination of polyphenols, Wollgast analyzed several solvents, finding that the most suitable mixture was acetone: water: acetic acid (70: 29.5: 0.5) v/v, which was used for the CCD optimization. The solubility of polyphenolic compounds in cocoa beans is affected by the solvent polarity; these compounds are poorly soluble when using pure solvents (methanol), as evidenced in the results shown in table 3. Zlotec et al. (2015) determined that the most proper solvent system for polyphenols in basil leaves extracts (Ocimum basilicum L.) (frozen matrices) was acetone: water: acetic acid (70: 29.5: 0.5) v/v. The solvent mixtures acetone-water increases the solubility of phenolic compounds due to its high polarity (23).
The main effects plot shows a variation directly proportional between the studied levels of the factors: solute-solvent ratio and temperature regarding the response variable. When the solutesolvent ratio was increased $(1: 10$ to $1: 20)$ and the extraction temperature $\left(20\right.$ to $\left.40^{\circ} \mathrm{C}\right)$, the value of the response variable total polyphenols also presented this behavior. However, for the time extraction factor, a progressive increase was observed and later a decrease in the response variable, which indicates that at this inflection point, the optimum point was reached for the time extraction factor. Gil et al. (2012) evaluated the extraction time using ultrasound to determine polyphenols, reaching up to 60 minutes without finding the inflection point. In this work, the methodology was set to evaluate up to 90 minutes, which found an inflection or optimal point for the time factor at approximately 75 minutes. The inflection point for the extraction time is explained for the cavitation phenomenon, which occurs for prolonged sonication times. This phenomenon can be the cause of degradation that polyphenol compounds in the extraction. (24)

Roso and Toro (2011) in their work about the optimization in polyphenols extraction from Hilacha Mango kernel (Mangifera indica Var), which indicated an increase in the phenols content due to the increment in the extraction temperature, generated the rise in these compounds solubility in the solvent. Another hand, the heating in the extraction can soften vegetable tissues, weaken the cell wall advantage release of phenolic compounds (22).

The Solute-solvent ratio was the most important parameter influencing the total polyphenols content. The optimal value was $22.97 \mathrm{~mL}$ of solvents. The S-S ratio had a positive effect on the extraction yield. The higher extraction of polyphenols when the S-S ratio increased is mainly due to mass transfer principles. Some authors, as Radojkovi et al. (2012) explained that the driving force during mass transfer is the concentration gradient between the solid and the bulk of the liquid, which is greater when a higher solvent to solid ratio is used (25-26). Some research has determined that yield in the extraction of polyphenols compounds from diverse materials depends on properties and structure of the compound, degree of polymerization, and its relation to the polarity of the solvent used in the extraction. (27-28). 
The interaction plot showed that the temperature/ time relationship had a greater effect with a lower value than the studied time, which was consistent with the effect of the response decreasing with a higher time frame (see figure 2). For the temperature/solute-solvent ratio interaction, an opposite effect was observed since the solute:solvent ratio gave the most pronounced effect. For the time/solute-solvent interaction, a similar effect was observed for both the minor and the higher temperatures. This interaction showed an inflection point coincident with the main effect of the time extraction.

\section{Total Polyphenols Quantification in Cocoa samples by Folin-Ciocalteu Method}

Regional material from Tumaco-Colombia CCL-02 had the highest content of polyphenols (59.27 mg GAE/g). Zapata et al. (3) reported values of total phenols in a range of 21.69 to $38.64 \mathrm{mg} \mathrm{GAE} / \mathrm{g}$ of cocoa beans without ferment. The content of total polyphenols in unfermented and dried cocoa beans from different countries is variable. Ivory Coast in cocoa beans samples of Forastero variety reports a value of $81.5 \mathrm{mg} \mathrm{GAE} / \mathrm{g}$. Perú in the beans of criollo variety $0.5 \mathrm{mg}$ GAE/g; Venezuela Trinitario variety $64.3 \mathrm{mg} \mathrm{GAE} / \mathrm{g}$, Colombia Amazon variety 81.4 $\pm 3.7 \mathrm{mg} \mathrm{GAE} / \mathrm{g}$ (29). Colombia, CCN-51 Clone from Santander region, the value was $73.48 \pm 4.93$ mg GAE/g (6). The content and composition of polyphenols in cocoa beans depend on many factors such as genotype, origin, type of clone, and growth conditions.

\section{CONCLUSIONS}

The solvent mixture of acetone: water: acetic acid (70:29.5:0.5) was found as the solvent system that presented the highest yield in polyphenols extractions from cocoa samples according to the statistical analysis. The results obtained from the design of experiments of the CCD confirmed that all the factors considered had a significant influence on the amount of total polyphenols extracted. According to the optimization with CCD, the conditions that maximize the extraction method of polyphenols using ultrasound-assisted extraction were: temperature of $39.3^{\circ} \mathrm{C}$, solvent-solute ratio $1 \mathrm{~g} / 22.8 \mathrm{~mL}$, and time of $74.5 \mathrm{~min}$. The optimal response of total polyphenol value is $40.33 \mathrm{mg}$ gallic equivalent acid/g of cocoa beans.

\section{CONFLICT OF INTEREST}

The authors do not have any kind of conflict of interest.

\section{ACKNOWLEDGEMENTS}

The authors would like to thank the Consejo Comunitario El Rescate-Las Varas- Municipio de Tumaco-Nariño and Sistema General de Regalías. Fondo de Ciencia, Tecnología e Innovación.

\section{REFERENCES}

1. Motilva, M., Serra, A., Macià, A. Analysis of food polyphenols by ultra high-performance liquid chromatography coupled to mass spectrometry: An overview. Journal of Chromatography A. 2013 ; 1292:66- 82. DOI: https://doi.org/10.1016/j. chroma.2013.01.012

2. Tzima, K., Brunton, N.P., Rai, D.K. Qualitative and Quantitative Analysis of Polyphenols in Lamiaceae Plants-A Review. Plants. 2018; 7, 25. DOI: https://doi.org/10.3390/ plants 7020025

3. Zapata Bustamante, S., Tamayo Tenorio, A., \& Rojano, B. Efecto de la fermentación sobre la actividad antioxidante de diferentes clones de cacao colombiano. Revista Cubana de Plantas Medicinales. 2013; 18(3): 391-404. Available in: http://www. revplantasmedicinales.sld.cu/index.php/pla/article/view/68/22

4. Urbańska, B.; Kowalska, J. Comparison of the Total Polyphenol Content and Antioxidant Activity of Chocolate Obtained from Roasted and Unroasted Cocoa Beans from Different Regions of the World. Antioxidants.2019; 8, 283. DOI: https://doi. org/10.3390/antiox8080283

5. EFSA Panel on Dietetic Products, Nutrition and Allergies (NDA); Scientific Opinion on the substantiation of a health claim related to cocoa flavanols and maintenance of normal endothelium-dependent vasodilation pursuant to Article 13(5) of Regulation (EC) No 1924/2006. EFSA Journal 2012; 10(7):2809. DOI: https://doi.org/10.2903/j.efsa.2012.2809

6. Pallares Pallares PA, Estupiñán MR, Perea Villamil JA, López Giraldo LJ. Impacto de la fermentación y secado sobre el contenido de polifenoles y capacidad antioxidante del clon de cacao CCN-51. rev.ion. 2016;29(2):7-21. DOI: http://dx.doi. org/10.18273/revion.v29n2-2016001

7. Kothe, L.; Zimmermann, B.F.; Galensa, R. Temperature influences epimerization and composition of flavanol monomers, dimers and trimers during cocoa bean roasting. Food Chem. 2013, 141, 3656-3663. DOI: https://doi. org/10.1016/j.foodchem.2013.06.049

8. Rajbhar K.; Dawda, H.; Mukundan, U. Polyphenols: Methods Of Extraction. Sci. Revs. Chem. Commun.: 5(1), 2015, 1-6. Available in: https://www.researchgate.net/ publication/312554206_Polyphenols_methods_of_extraction

9. MdYusof, A.H.; Abd Gani, S.S.; Zaidan, U.H.; Halmi, M.I.E.; Zainudin, B.H. Optimization of an Ultrasound-Assisted Extraction Condition for Flavonoid Compounds from Cocoa Shells (Theobroma cacao) Using Response Surface Methodology. Molecules 2019, 24, 711. DOI: https://doi.org/10.3390/ molecules24040711

10. Chirinos, R., Rogez, H., Campos, D., Pedreschi, R., \& Larondelle, Y. Optimization of extraction conditions of antioxidant phenolic compounds from mashua (Tropaeolum tuberosum Ruíz \& Pavón) tubers. Separation and Purification Technology. 2007; 55(2), 217-225. DOI: https://doi.org/10.1016/j. seppur.2006.12.005 
11. Pinelo, M., Rubilar, M., Sineiro, J., \& Nunez, M. J. Extraction of antioxidant phenolics from almond hulls (Prunus amygdalus) and pine sawdust (Pinus pinaster). Food Chemistry; 2004; 85(2), 267-273. DOI: https://doi.org/10.1016/j.foodchem.2003.06.020

12. Quiroz-Reyes, C. N., Aguilar-Méndez, M. A., Ramírez-Ortíz, M. E., \& Jesús, R. D. Estudio comparativo entre las técnicas de ultrasonido y maceración para la extracción de polifenoles del grano de cacao (Theobroma cacao L.). Rev Mex Ing Quím. 2013; 12(1), 11-18. Available in: http://www.scielo.org.mx/scielo. php?script $=$ sci_arttext\&pid=S1665-27382013000100002\&lng $=$ es\&nrm $=$ iso\&tlng $=$ en

13. Gu, L., House, S. E., Wu, X., Ou, B., \& Prior, R. L. Procyanidin and catechin contents and antioxidant capacity of cocoa and chocolate products. Journal of Agricultural and Food Chemistry.2006. 54(11), 4057-4061. DOI: https://doi. org/10.1021/jf060360r

14. Gil, A. Estabilidad y actividad antioxidante de catequinas presentes en cacaos colombianos durante los procesos de pre e industrialización. [Trabajo de grado para optar por el título de magíster en Ciencias Farmacéuticas]-[Medellín, Colombia]: Universidad de Antioquia: 2012.119 p. Available in: http://bibliotecadigital.udea.edu.co/bitstream/10495/1621/1/ TESIS\%20Jorge\%20Andres\%20Gil\%20FINAL.pdf

15. Wollgast, J. The contents and effects of polyphenols in chocolate, Qualitative and quantitative analices of polyphenols in chocolate and chocolate raw products as well as evaluation of potencial implications of chocolate in human health. [Tesis de Doctorado]- [Gießen-Alemania]: Instituto de Ciencias Nutricionales. Facultad de Agricultura y Ciencias de Nutrición, Economía y Administración Ambiental. Universidad de Gieben: 2004. 349 p. Available in: https://d-nb.info/976395355/34

16. Alañón, M. E., Castle, S. M., Siswanto, P. J., Cifuentes-Gómez, T., \& Spencer, J. P. E. Assessment of flavanol stereoisomers and caffeine and theobromine content in commercial chocolates. Food chemistry. 2016. 208, 177-184. DOI: https://doi. org/10.1016/j.foodchem.2016.03.116

17. Di Mattia, C., Martuscelli, M., Sacchetti, G., Scheirlinck, I., Beheydt, B., Mastrocola, D., \& Pittia, P. Effect of fermentation and drying on procyanidins, antiradical activity and reducing properties of cocoa beans. Food and Bioprocess Technology. 2013. 6(12): 3420-3432. https://doi.org/10.1007/s11947-0121028-x

18. Cadena, T. y Herrera, Y. Evaluación del efecto del procesamiento del cacao sobre el contenido de polifenoles y su actividad antioxidante. [Tesis de grado química]-[BucaramangaColombia] Facultad de Ciencias-Universidad Industrial de Santander: 2008. 91 p. Available in: http://tangara.uis.edu.co/ biblioweb/tesis/2008/128865.pdf

19. Redovnikovic, I. R., Delonga, K., Mazor, S., Dragovic-Uzelac, V., Caric, M., \& Vorkapic-Furac, J. Polyphenolic content and composition and antioxidative activity of different cocoa liquors. Czech journal of food sciences. 2009. 27(5), 330-337. Available in: https://www.agriculturejournals.cz/publicFiles/119_2008CJFS.pdf
20. Pan, Z., Qu, W., Ma, H., Atungulu, G. G., \& McHugh, T. $\mathrm{H}$. Continuous and pulsed ultrasound-assisted extractions of antioxidants from pomegranate peel. Ultrasonics sonochemistry. 2011. 18(5), 1249-1257. DOI: https://doi.org/10.1016/j. ultsonch.2011.01.005

21. Larrea Posadas, Javier. Obtención de extractos polifenólicos a partir de uva para uso alimentario. [Trabajo de Maestría en Tecnología y Calidad de las Industrias Alimentarias]. [NavarraEspaña]: Universidad Pública de Navarra. 2012.99 p. Available in: https://academica-e.unavarra.es/handle/2454/6531

22. Rosso, A. M. y Toro, S. Optimización de las condiciones de extracción sólido-líquido de polifenoles a partir de la almendra de mango hilacha (Manguifera indica) y ajuste de sus parámetros cinéticos. [Trabajo de Grado de Ingeniería Química].[Bucaramanga-Colombia]. Universidad Industrial de Santander. 2011. 59 p. Available in: http://tangara.uis.edu. co/biblioweb/tesis/2011/141001.pdf

23. Złotek. U., Mikulska. S., Nagajek. M, Swieca. M. The effect of different solvents and number of extraction steps on the polyphenol content and antioxidant capacity of basil leaves (Ocimum basilicum L.) extracts. Saudi Journal of Biological Sciences. 2016; 23: 628-633. DOI: https://doi.org/10.1016/j. sjbs.2015.08.002

24. Arroyo, J., y Flores, J. Degradación ultrasónica de contaminantes orgánicos. Revista Peruana de Química e Ingeniería Química. 2001; 4(2): 3-14. Available in: https://revistasinvestigacion. unmsm.edu.pe/index.php/quim/article/view/4267/3408

25. Radojkovi. M, Zekovi. Z, Joki S, Vidovi S, Lepojevi. Z, Milo S. Antioxidant Extraction from Black Mulberry Leaf, Food Technol. Biotechnol. 2012; 50 (2):167-176.

26. Elboughdiri. N. Effect of Time, Solvent-Solid Ratio, Ethanol Concentration and Temperature on Extraction Yield of Phenolic Compounds From Olive Leaves. Engineering, Technology \& Applied Science Research. 2018; 8(2): 2805-2808. DOI: https:// doi.org/10.13140/RG.2.2.26002.81601

27. Soto-García M, Rosales-Castro. M. Efecto del solvente y de la relación masa/solvente sobre la extracción de compuestos fenólicos y la capacidad antioxidante de extractos de corteza de Pinus Durangensis y Quercus Sideroxyla. Maderas. Ciencia y tecnología. 2016: 18(4): 701 - 714. DOI: http://dx.doi. org/10.4067/S0718-221X2016005000061

28. Spigno, G.; Tramelli, L.; De Faveri, D. M. Effects of extraction time, temperature and solvent on concentration and antioxidant activity of grape marc phenolics. Journal of Food Engineering. 2007; 81(1):200-208. DOI: https://doi. org/10.1016/j.jfoodeng.2006.10.021

29. Chávez-Rivera,R.E., Ordoñez- Gómez, S. Total polyphenols, anthocyanins and antioxidant capacity (DPPH and ABTS) during processing of cocoa liquor and cocoa powder. 2013; 10 (1): 42-50. Available in: https://dialnet.unirioja.es/servlet/ articulo?codigo $=4814490$ 